\title{
IMPLEMENTASI KODE ETIK GURU DALAM PEMBELAJARAN PENDIDIKAN AGAMA ISLAM DI SMA NEGERI 1 SUKODADI LAMONGAN
}

\author{
Ahmad Hanif Fahruddin \\ Universitas Islam Lamongan, Indonesia \\ E-mail: kanghanif88@unisla.ac.id \\ Eva Nur Tita Sari \\ Universitas Islam Lamongan, Indonesia \\ E-mail: evanurtitasari@gmail.com
}

\begin{abstract}
Abstrak: Penelitian ini hendak melihat bagaimana kode etik guru yang juga berstatus pegawai negeri sipil diimplementasikan dalam proses pembelajaran pendidikan agama Islam di sekolah menengah atas. Penelitian ini berjudul implementasi kode etik guru dalam pembelajaran pendidikan agama Islam di SMA Negeri 1 Sukodadi Lamongan. Penelitian ini menggunakan jenis penelitian kualitatif serta pendekatan diskriptif, dan menggunakan metode observasi, wawancara, dokumentasi. Tujuan dari penelitian ini adalah untuk mengetahui implementasi kode etik guru dalam pembelajaran pendidikan Agama Islam, serta model implementasi kode etik dalam pembelajaran pendidikan Agama Islam di SMA Negeri 1 Sukodadi Lamongan. Hasil dari penelitian ini, yang pertama adalah implementasi kode etik guru dalam pembelajaran Pendidikan Agam Islam dengan cara menjadi suri tauladan, terbuka, fleksibel, dan adil sedangkan Model implementasi kode etik dalam pembelajaran pendidikan agama Islam diterapkan dengan pembiasan dan keteladanan.
\end{abstract}

Kata kunci: implementasi, kode etik, pendidikan agama Islam

\section{Pendahuluan}

Akhir-akhir ini pendidikan menjadi masalah yang ramai dibicarakan. Salah satunya, masih ada guru yang belum bisa dijadikan suri tauladan ketika di luar sekolah. Ada pula seorang guru dalam menjalankan profesinya menyimpang atau melakukan pelanggaran terhadap norma-norma seorang guru. Padahal etika guru merupakan salah satu faktor pendukung keberhasilan pendidikan. Pendidikan adalah investasi sumber daya manusia jangka panjang yang mempunyai nilai strategis bagi kelangsungan peradaban manusia didunia.Pengaruh dalam pendidikan ini sangatlah luas dan besar, serta mendalam. ${ }^{1}$

Guru merupakan profesi yang dapat menentukan masa depan bangsa ini, guru yang baik dan berkualitas dapat menjadikan bangsa ini menjadi bangsa yang berkualitas juga, begitu juga sebaliknya, seorang guru yang tidak berkualitas akan menjadikan bangsa ini menjadi bangsa yang terjajah lagi. Pengaruh yang diperoleh anak didik disekolah hampir seluruhnya berasal dari guru. Karena, sejarah membuktikan bahwa guru yang tidak mempunyai kompetensi dan kualifikasi mengajar, menyebabskan kualitas pendidikan menjadi tidak bermutu dan tidak diperhatikan oleh

${ }^{1}$ Muhammad Rahman, dan Sofan Amri, Kode Etik Profesi Guru Legalitas, Realitas, dan Harapan (Jakarta: Prestasi Pustakarya, 2014), 55. 
masyarakat, bahkan masyarakat kurang menghargai guru sebagai individu, maupun sebagai anggota masyarakat. ${ }^{2}$

Guru adalah pendidik yang menjadi tokoh, panutan dan identifikasi bagi peserta didik, dan lingkungannya. Oleh karena itu, guru harus memiliki standar kualitas tertentu, yang mencakup tanggung jawab, wibawa, mandiri, dan disiplin. Peran guru sebagai pendidik berkaitan dengan meningkatkan pertembuhan dan perkembangan anak untuk memperoleh pengalamanpengalaman lebih lanjut seperti penggunaan kesehatan jasmani, bebas dari orang tua, dan orang dewasa yang lain, moralitas tanggung jawab kemasyarakatan, pengetahuan dan keterampilan dasar, persiapan untuk perkawinan dan hidup berkeluarga, pemilihan jabatan, dan hal-hal yang bersifat personal dan spiritual. Oleh karena itu, tugas guru dapat disebut pendidik dan pemeliharaan anak. Guru sebagai penanggung jawab pendisiplinan anak harus mengontrol setiap aktivitas anak-anak agar tingkah laku anak tidak menyimpang dengan norma-norma yang ada. ${ }^{3}$ Sehingga pemerintah menetapkan suatu aturan atau norma-norma yang harus dipatuhi oleh seluruh guru di Indonesia yang dikenal dengan "kode etik guru" .dengan adanya kode etik guru ini, diharapkan para guru dapat menjalankan tugasnya dengan baik.

Pada umumnya kode merupakan landasan moral pedoman sikap, tingkah laku.Sanksi terhadap pelanggaran kode etik adalah sanksi moral. Barang siapa melanggar kode etik, akan mendapat cela dari rekan-rekannya, sedangkan sanksi yang yang dianggap terberat adalah pelanggar dikeluarkan dari organisasi profesi tersebut. Adapun maksud dan tujuan pokok diadakannya kode etik adalah untuk menjamin agar tugas pekerjaan keprofesian itu terwujud sebagaimana mestinya dan kepentingan semua pihak terlindungi sebagaimana layaknya. ${ }^{4}$

Interprestasi tentang kode etik belum memiliki pengertian yang sama. Berikut ini adalah beberapa pengertian mengenai kode etik. Undang-undang Nomor 8 tahun 1974 tentang pokokpokok kepegawaian. Pasal 28 menyatakan bahwa "pegawai negeri sipil mempunyai kode etik sebagai pedoman sikap, tingkah laku perbuatan di dalam dan di luar kedinasan." ${ }^{5}$

Dalam penjelasan undang-undang tersebut dinyatakan dengan adanya kode etik ini, Pegawai Negeri Sipil sebagai Aparatur Negara, Abdi Negara, dan Abdi Masyarakat, mempunyai pedoman sikap, tingkah laku, dan perbuatan dalam melaksanakan tugasnya dan dalam pergaulan hidup sehari-hari. Oleh sebab itu, kunci keberhasilan guru dalam meningkatkan prestasi belajar siswa adalah memiliki kode etik yang baik. Adapun tujuan mengimplementasikan kode etik guru ialah ; untuk menjujung tinggi kode etik guru, untuk menjaga dan memelihara kesejahteraan para

\footnotetext{
2 Armai, Arief, Pengantar ilmu dan Metodologi Pendidikan Islam (Jakarta: Ciputat pres, 2002), 67.

3 Muhammad Rahman, dan Sofan Amri, Kode Etik Profesi Guru Legalitas, Realitas, dan Harapan (Jakarta: Prestasi Pustakarya, 2014), 107.

${ }^{4}$ Rahman, dan Sofan Amri, Kode Etik Profesi Guru, 107.

${ }^{5}$ Undang-Undang RI No8 tahun 1974 Tentang Pokok-pokok Kepegawaian (Jakarta: Prestasi Pustakarya, 2014$), 1$. 
anggotanya, untuk meningkatkan pengabdian anggota profesi, dan untuk meningkatkan mutu organisasi profesi.

Menurut pandangan Islam pendidikan merupakan proses yang berawal dari saat Allah SWT. sebagai rabb al-'alamin yang menciptakan para Nabi dan rasul untuk mendidik manusia dimuka bumi. Pada hakikatnya kata "rabb" yang berarti Tuhan dan "murobbinya" yang berarti pendidik. Sebagaimana firman Allah Swt dalam surat Al-Israa'; 24.

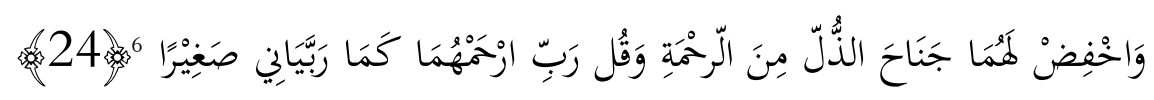

Artinya: Dan rendabkanlah dirimu terhadap mereka berdua dengan penuh kesayangan dan ucapkanlah "Wabai Tubanku, kasibilabkeduanya sebagaimana keduanya telab mendidik aku waktu aku kecil"?

Maka dapat disimpulkan bahwa guru pendidikan Agama Islam adalah seorang yang bertanggung jawab dalam melaksanakan pendidikan Agama Islam dan bertanggung jawab dalam membentuk pribadi siswa agar sesuai dengan ajaran Islam.

Dalam pembelajaran pendidikan agama Islam tingginya kedudukan guru dalam Islam realisasi ajaran itu sendiri. Islam memuliakan pengetahuan, pengetahuan itu didapat dari belajar dan mengajar, yang belajar adalah calon guru dan yang mengajar adalah guru. Maka, Islam pasti memuliakan guru. Tidak terbayangkan terjadinya perkembangan pengetahuan tanpa adanya orang belajar dan tanpa adanya guru. Karena Islam adalah agama, maka pandangan tentang guru dan kedudukannya, tidak terlepas dari nilai-nilai agama. Kedudukan tinggi bagi guru dalam Islam memiliki alasan duniawi dan alasan ukhrawi, atau alasan bumi dan alasan langit. ${ }^{8}$ Para guru pendidikan agama Islam di SMA Negeri 1 Sukodadi Lamongan dan kepala sekolahnya memiliki semangat mengajar serta tingkah laku yang baik, seperti halnya berangkat sekolah tepat waktu dan bahasa yang digunakan juga sopan. Hal semacam ini bisa ditiru oleh para peserta didiknya.

Menurut Ely Makiyah salah satu guru Pendidikan Agama Islam di SMA Negeri 1 Sukodadi menjelaskan bahwa kode Etik itu sama dengan rambu-rambu yang harus dipatuhi oleh seorang guru. Kode Etik Guru itu merupakan penjabaran dari Etika seorang guru, dimana guru mau tidak mau harus mematuhi dan menjalankannya. Karena, jika seorang guru mematuhi atau menjalankan etika atau aturan yang berlaku disuatu sekolah otomatis kewibawaan seorang guru bisa terjaga dimata siswa maupun orang lain. Dan semua guru harus mentaatidan menjalankan kode etik, terutama guru agama yang merupakan contoh atau tauladan bagi guru-guru lain".

\footnotetext{
${ }^{6}$ Al-Qur'an, 24:18

${ }^{7}$ Departemen Agama RI, Al-Qur'an dan terjemahnya (Bandung: CV. Penerbit J-ART, 2005), 284.

${ }^{8}$ Ahmad Tafsir, Ilmu Pendidikan Islam (Bandung: PT Remaja Rosdakarya Offset, 2013), 123.

${ }^{9}$ Ely Makiyah, Wawancara, Lamongan, 24 Desember 2019.
} 
Ini membuktikan bahwa implementasi kode etik guru sangat diperlukan dalam melaksanakan tugas dan tanggung jawabnya sebagai seorang pendidik, apalagi guru merupakan salah satu faktor terpenting dalam proses pendidikan. Sebab gurulah sebenarnya pemain yang paling menentukan didalam terjadinya proses pembelajaran. terkhusus guru pendidikan agama Islam, seperti yang di katakan oleh Ely Makiyah bahwa seorang guru agama adalah contoh untuk peserta didik dan guru lainnya.

Karena alasan diataslah peneliti tertarik untuk meneliti Kode Etik guru dalam Pembelajaran Pendidikan Agama Islam di SMA Negeri 1 Sukodadi Lamongan. Berdasarkan latar belakang dari permasalahan diatas, maka dapat dirumuskan masalahnya Bagaimana Implementasi Kode Etik Guru dalam pembelejaran PAI di SMA Negeri 1 Sukodadi Lamongan, dan Bagaimana model Implementasi Kode Etik Guru dalam Pembelajaran PAI di SMA Negeri 1 Sukodadi Lamongan.

\section{Implementasi Kode Etik Guru}

Sebelum membahas bagaimana kode etik diimplementasikan, secara terminologis implementasi dimaknai sebagai pelaksanaan dan atau penerapan. Majone dan Wildavsky mengemukakan Secara sederhana implementasi bisa diartikan pelaksanaan atau penerapan serta implementasi sebagai evaluasi. Bowne dan Wildavsky mengemukakan bahwa implementasi adalah perluasan aktivitas yang yang saling menyesuaikan. Menurut Mclaughin juga mengemukakan sama seperti ini. Adapun Schubert menegmukakan bahwa implementasi adalah sistem rekayasa. ${ }^{10}$

1. Kode Etik Guru

a. Pengertian Kode Etik Guru

Kata etik berasal dari bahasa Yunani, ethos yang berarti watak, adab atau cara hidup. Dapat diartikan bahwa etik itu menunjukan "cara berbuat menjadi ada karena persetujuan dari kelompok manusia" dan etik biasanya dipakai untuk pengkajian sistem nilai-nilai yang disebut kode sehingga muncullah apa yang dinamakan kode etik atau secara harfiah kode etik berarti sumber etik. Secara etimologis kode etik berarti pola aturan, tata cara, tanda, pedoman etis dalam melakukan kegiatan atau pekerjaan. Dalam kaitannya dengan istilah profesi, kode etik merupakan tata cara atau aturan yang menjadi standar kegiatan anggota suatu profesi. ${ }^{11}$

Kode etik guru diartikan aturan asusila tata-susila keguruan. Aturan-aturan tentang keguruan (yang menyangkut pekerjaan-pekerjaan guru) melibatkan dari segi usaha. Maksud dari kode etik guru disini adalah norma-norma yang mengatur hubungan kemanusiaan (relationship) antar guru dengan lembaga pendidikan (sekolah), guru dengan sesama guru,

\footnotetext{
${ }^{10}$ Muhammad Rahman dan Sofan Amri, Kode Etik Profesi Guru (Jakarta: Prestasi Pustakaraya, 2014), 59.

11 Akmal Hawi, Kompetensi Guru Pendidikan Agama Islam (Jakarta: PT Raja Grafindo Persada, 2013), 16.

154 | Tarbiyatuna: Jurnal Pendidikan Islam; Volume 13, Nomor 2, Agustus 2020, 151 -169 p-ISSN: 2085-6539; e-ISSN: 2242-4579
} 
guru dengan peserta didik, dan guru dengan lingkungannya. Sebagai sebuah jabatan pekerjaan, profesi guru memerlukan kode etik khusus untuk mengatur hubungan-hubungan tersebut. ${ }^{12}$ Sedangkan Menurut Gibson and Mitchel kode etik merupakan sebuah pedoman bagi masyarakat pengguna suatu profesi yang bertindak diluar kewajaran. ${ }^{13}$ Dalam buku Muhammmad Rahman dan Sofam berpendapat bahwa kode etik guru adalah sebuah ikatan, maksudnya adalah sebuah ikatan yang mengikat seluruh guru di Indonesia dan mengatur banyak hal seperti hubungan antara guru dengan peserta didik, orang tua, masyarakat, teman sejawat, dan organisasi profesi. ${ }^{14}$

Dengan adanya kode etik ini akan mengikatkan seluruh guru dan mengatur beberapa hal seperti hubungan antara guru dengan peserta didik, guru dengan orang tua, guru dengan masyarakat, guru dengan teman sejawat, dan guru dengan organisasi profesi. Guru yang dalam pelaksanaan tugas dan pengabdiannya menyalahi kode etik, akan diberi sanksi tegas sesuai dengan draf kode etik yang berlaku. Guru mengabdikan diri dan berbakti untuk mencerdaskan kehidupan bangsa dan meningkatkan kualitas manusia yang beriman, bertaqwa, dan berakhlak yang mulia serta menguasi ilmu pengetahuan, teknologi, dan seni dalam mewujudkan masyarakat yang maju, adil, makmur, dan beradab. ${ }^{15}$

Berdasarkan pembahasan di atas dapat ditegaskan bahwa kode etik adalah suatu istilah atau wacana yang mengacu kepada seperangkat perbuatan yang memiliki nilai, baik atau buruk, pantas atau tidak pantas, sopan atau tidak sopan. Kode etik tersebut harus ada dalam setiap pekerjaan profesional, termasuk guru.

b. Tujuan Kode Etik Guru

Pada dasarnya tujuan merumuskan kode etik dalam sutau profesi adalah untuk kepentingan anggota dan kepentingan organisasi profesi itu sendiri. Adapun maksud dan tujuan pokok diadakannya kode etik adalah menjamin agar tugas pekerjaan keprofesian itu terwujud sebagaimana mestinya dan kepentingan semua pihak terlindungi sebagaimana layaknya.

Secara umum tujuan mengadakan kode etik adalah sebagai berikut:

1) Menjujung tinggi martabat profesi kode etik dapat menjaga pandangan dan kesan pihak luar atau masyarakat, agar mereka tidak memandang rendah terhadap profesi yang bersangkutan. Oleh kareena itu, setiap kode etik suatu profesi akan melarang berbagai

\footnotetext{
12 Muhammad Rahman dan Sofan Amri, Kode Etik Profesi Guru (Jakarta: Prestasi Pustakaraya, 2014), 2.

${ }^{13}$ Rahman dan Amri, Kode Etik Profesi Guru, 20.

${ }^{14}$ Rahman dan Amri, Kode Etik Profesi Guru, 21.

15 Rahman dan Amri, Kode Etik Profesi Guru, 21.
} 
bentuk tindak tanduk atau kelakuan anggotanya yang dapat mencemarkan nama baik profesi.

2) Untuk menjaga dan memelihara kesejahteraan para anggotanya. Kesejahteraan mencakup lahir (material) maupun batin (spiritual, emosional, dan mental). Kode etik umumnya memuat larangan-larangan untuk melakukan perbuatan-perbuatan yang meugikan kesejahteraan para anggotanya. Misalnya dalam menetapkan tarif-tarif minimum bagi honorarium anggita profesi dalam melaksanakan tugasnya, sehingga siapa saja yang mengadakan tarif di bawah minimum akan dianggap tercela dan merugikan teman seprofesi. Dalam hal kesejahteraan batin, ode etik umumnya memberi petunjukpetunjuk kepada anggotanya untuk melaksanakan profesinya.

3) Pedoman berperilaku kode etik mengandung peraturan yang membatasi tingkah laku yang idak pantas dan tidak jujur bagi para anggota profesi dalam berinteraksi dengan sesama rekan anggota profesi.

4) Untuk meningkatkan pengabdian anggota profesi, kode etik berkaitan dengan peningkatan kegiatan pengabdia profesi, sehingga bagi para anggota profesi dapat dengan mudah mengetahui tugas dan tanggung jawab pengabdiannya dalam melaksanakan tugasnya. Oleh karena itu, kode etik merumuskan ketentuan-ketentuan yang perlu dilakukan para anggota profesi dalam menjalankan tugasnya.

5) Untuk meningkatkan mutu profesi kode etik memuat norma-norma dan anjuran agar para anggota profesi selalu berusaha untuk meningkatkan mutu pengabdian para anggotanya.

6) Untuk meningkatkan mutu organisasi profesi kode etik mewajibkan seluruh anggotanya untuk aktif berpartisipasi dalam membina organisasi profesi dan kegiatan-kegiatan yang dirancang organisasi. ${ }^{16}$

Dari uraian di atas dapat disimpulkan bahwa tujuan suatu profesi menyusun kode etik adalah untuk menjujung tinggi martabat profesi, menjaga dan memelihara kesejahteraan para anggotan, meningkatkan mutu profesi serta mutu organisasi profesi.

c. Fungsi Kode Etik Guru

Pada dasarnya kode etik berfungsi sebagai, perlindungan dan pengembangan bagi profesi itu, dan sebagai pelindung bagi masyarakat pengguna jasa pelayanan suatu profesi. Kode etik guru dirancang untuk dijadikan pedoman berperilaku bagi guru dimana dan dalam arena apapun ia berada.

Secara umum fungsi kode etik guru yakni;

${ }^{16}$ Rahman dan Amri, Kode Etik Profesi Guru, 75.

156 | Tarbiyatuna: Jurnal Pendidikan Islam; Volume 13, Nomor 2, Agustus 2020, 151 -169 p-ISSN: 2085-6539; e-ISSN: 2242-4579 
1) Agar guru mempunyai pedoman dan arah yang jelas dalam melaksanakan tugas, sehingga terhindar dari penyimpangan profesi.

2) Agar guru bertanggung jawab atas profesinya.

3) Agar guru terhindar dari perpecahan dan pertentangan internal.

4) Mampu meningkatkan kualitas dan pelayanan sehingga jasa guru diakui dan digunakan oleh masyarakat.

5) Dapat membantu memecahkan masalah dan mengembangkan diri.

6) Agar profesi guru terhindar dari campur tangan profesi lain dan pemerintah.

\section{Pembelajaran Pendidikan Agama Islam}

1. Pembelajaran Pendidikan Agama Islam

Dalam bahasa Arab pengertian pendidikan, sering digunakan beberapa istilah antara lain, al-ta'lim, al-tarbiyah, dan at-tadib. Al-ta'lim berarti pengajaran yang bersifat pemberian atau penyampaian pengetahuan dan keterampilan. Al-tarbiyah berarti mengasuh mendidik dan alta'dib lebih condong pada proses mendidik yang bermuara pada penyempurnaan akhlak atau moral peserta didik. Namun, kata pendidikan ini lebih sering dikatakan dengan tarbiyah yang berarti pendidikan. ${ }^{17}$

Pendidikan Agama Islam adalah suatu usaha bimbingan dan asuhan terhadap anak didik agar nantinya setelah selesai dari pendidikan dapat memahami apa yang terkandung dalam ajaran islam secara keseluruhan, mengkhayati makna dan maksud serta tujuannya dan pada akhirnya dapat mengamalkannya serta menjadikan ajaran-ajaran agama islam yang telah dianutnya itu sebagai pandangan hidupnya sehingga dapat mendatangkan keselamatan dunia dan akhiratnya kelak. ${ }^{18}$

2. Dasar dan Tujuan Pembelajaran Pendidikan Agama Islam.

Dasar atau pondasi pendidikan Agama Islam ada di dalam al-qur'an dan al- hadist. Keduanya merupakan sumber hokum Islam yang dapat diyakini kebenarannya, hal ini sama seperti Firman Allah SW'T yaitu:

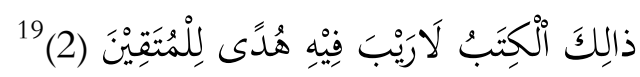

Artinya: "Kitab (Al-quran) ini tidak ada keraguan padanya pentunjuk mereka yang bertaqwa." (QS. Al-Baqoroh: 2). ${ }^{20}$

\footnotetext{
${ }^{17}$ Muhammad Sabiqul Khoiri, "Efektifitas Penggunaan Metode Jigsaw Learning Dalam Pembelajaran Pendidikan Agama Islam di Kelas VII SMPN 2 Deket Tahun Pelajaran 2015/2016" (Skripsi-Universitas Islam Lamongan, 2016), 7.

${ }^{18}$ Zakiyah Darajar, dkk, Ilmu Pendidikan Islam (Jakarta: Bumi Aksara, 2008), 88.

${ }^{19} \mathrm{Al}-\mathrm{Quran}, 24$
} 
Adapun dalam hadist Nabi Muhammad yang dapat dijadikan sumber pendidikan agama Islam adalah yakni hadis riwayat Imam Muslim, "Dari Ibnu Abbas RA. Rosulullah SAW bersabda: telah aku tinggalkan dua perkara yang apabila kamu berpegang kepada keduanya, niscaya tidak akan sesat yaitu kitabullah dan sunatullah.”

Terbentuknya peserta didik yang beriman dan bertawa kepada Allah SWT. Setidaknya memiliki ciri:
a. Berbudi pekerti yang luhur (berakhlak mulia).
b. Memiliki pengetahuan tentang ajaran pokok agama Islam.
c. Mengamalkannya dalam kehidupan.

3. Fungsi Pembelajaran Pendidikan Agama Islam

Pendidikan Agama Islam, baik sebagai proses penanaman keimanan dan seterusnya maupun sebagai materi (bahan ajar) memiliki fungsi yang jelas, yaitu;

a. Sebagai pengembangan, yaitu untuk meningkatkan keimanan dan ketawaan peserta didik kepada Allah SWT, yang telah ditanamkan dalam lingkungan keluarga.

b. sebagai penyaluran, yaitu untuk menyalurkan peserta didik yang memiliki bakat khusus dibidang agama agar bakat tersebut dapat berkembang secara optimal, sehingga dapat dimanfaatkan untuk orang lain dan dirinya sendiri.

c. Sebagai perbaikan, yaitu untuk memperbaiki kesalahan, kekurangan, dan kelemahan peserta didik dalam keyakinan, pemahaman dan pengalaman ajaran Agama Islam yang sebelumnya mungkin mereka peroleh melalui sumber-sumber yang ada di lingkungan keluarga dan masyarakat.

d. Sebagai pencegahan, yaitu menangkal hal-hal negatif dari lingkungan peserta didik atau dari budaya lain yang dapat membahayakan dirinya dan menghambat perkembangan menuju manusia Indonesia seutuh nya.

e. Sebagai penyesuaian mental, yaitu meneysuaikan diri dengan lingkungannya, baik lingkungan fisik maupunsosial dan dapat mengubah lingkungannya sesuai dengan ajaran Agama Islam.

f. sebagai penanaman nilai, yaitu memberikan pedoman hidup untuk mencapai kebahagiaan. ${ }^{21}$

${ }^{20}$ Departemen Agama RI, Al-Qur'an dan terjemahnya (Bandung: CV Penerbit J-ART, 2005), 3.

${ }^{21}$ M. Fatchul Ulumuddin, "Implementasi Pendidikan Karakter Melalui Pembelajaran Pendidikan Agama Islam di Mts Al-Ihsan Pondok Pesantren Darul Fiqhi Deket Lamongan” (Skripsi - Universitas Islam Lamongan, 2019), 44.

158 | Tarbiyatuna: Jurnal Pendidikan Islam; Volume 13, Nomor 2, Agustus 2020, 151 -169 p-ISSN: 2085-6539; e-ISSN: 2242-4579 


\section{Kode Etik Guru Dalam Pembelajaran Pendidikan Agama Islam}

Kode etik guru diartikan aturan asusila tata-susila keguruan. Aturan-aturan tentang keguruan (yang menyangkut pekerjaan-pekerjaan guru) melibatkan dari segi usaha. ${ }^{22}$ Dalam kongkres PGRI ke XIII pada 21-25 November 1973 di Jakarta, dirumuskan sembilan item kode etik, yakni:

a. Berbakti dalam membimbing peserta didik.

b. Memiliki kejujuran profesional dalam melaksanakan kurikulum sesuai dengan kebutuhan masing-masing peserta didik.

c. Mengadakan komunikasi untuk mendapatkan informasi tentang peserta didik.

d. Menciptakan suasana belajar yang kondusif dan mengadakan hubungan dengan orang tua siswa.

e. memelihara hubungan dengan untuk kepentingan pendidikan.

f. secara individu atau kelompok mengembangkan profesi.

g. Menciptakan dan memelihara hubungan baik antar pendidik.

h. Secara bersama-sama mememlihara dan meningkatkan mutu organisasi profesi.

i. Melaksanakan segala kebijakan pemerintah dalam bidang pendidikan. ${ }^{23}$

Pada dasarnya tujuan merumuskanya kode etik dalam suatu profesi adalah untuk kepentingan anggota dan organisasi profesi itu sendiri.Sedang secara umum tujuan dari mengadakan kode etik guru adalah untuk menjujung tinggi martabat profesi, untuk memelihara kesejahteraan para anggotanya, untuk meningkatkan mutu profesi dan mutu organisasi profesi.

Kode etik guru Indonesia adalah norma dan asas yang disepakati dan diterima oleh guruguru Indonesia sebagai pedoman sikap dan perilaku dalam melaksanakan tugas profesi sebagai pendidik, anggota masyarakat dan warga Negara. Adapun kode etik guru Indonesia sebagai berikut ;

a. Guru berbakti membimbing anak didik seutuhnya untuk membentuk mansuia yang berjiwa Pancasila.

b. Guru memiliki kejujuran professional dalam menerapkan kurikulum sesuai dengan kebutuhan anak didik masing-masing.

c. Guru menciptakan suasana kehidupan sekolah dan memelihara hubungan dengan orang tua murid sebaik-baiknya bagi kepentingan anak didik.

d. Guru memelihara hubungan dengan masyarakat sekitar sekolahan maupun masyarakat yang luas untuk kepentingan pendidikan.

22 Rahman dan Amri, Kode Etik Profesi Guru, 2.

23 Syafruddin, Nurdin, Andriantoni. Profesi Keguruan (Jakarta: PT Rajagrafindo Persada, 2019), 141. 
e. Guru secara sendiri-sendiri atau bersama-sama berusaha mengembangkan dan meningkatkan mutu profesinya.

f. Guru menciptakan dan memelihara hubungan antara sesame guru baik berdasarkan lingkungan maupun didalam hubungan keseluruhan.

g. Guru bersama-sama memelihara membina dan meningkatka mutu organisasi guru professional sebagai sarana pengabdian.

h. Guru melaksanakan segala ketentuan yang merupakan kebijakan pemerintah dalam bidang pendidikan. $^{24}$

Menurut Imam Al-Ghozali dalam kitabnya Ihya' ulumuddin dijelaskan bahwa kode etik dan tugas guru sebagai berikut :

a. Kasih sayang kepada peserta didik dan memperlakukannya seperti anaknya sendiri.

b. Meneladani Rosulullah sehingga jangan menuntut upah, imbalan atau penghargaan.

c. hendaknya tidak memberikan predikat atau martabat kepada peserta didik sebelum ia pantas dan kompeten untuk menyandangnya, dan jangan memberi ilmu yang al-ilm al-khafy (samar) sebelum tuntas ilmu yang al-ilm al-jali (jelas).

d. Hendaknya mencegah peserta didik dari akhlak yang buruk.

e. Guru yang memegang bidang studi tertentu sebaiknya tidak meremehkan bidang studi lain.

f. menyajikan pelajaran sesuai dengan taraf kemampuan peserta didik.

g. Dalam menghadapi peserta didik yang kurang mampu sebaiknya diberi ilmu-ilmu yang global dan tidak perlu menyajikan detailnya.

h. Guru hendaknya mengamalkan ilmunya, dan jangan sampai ucapannya bertentangan dengan perbuatannya. ${ }^{25}$

Dari uraian tersebut, satu hal yang menarik tentang teori kode etik pendidik yang dikembangkan oleh Imam Al-Ghozali, yaitu terdapat unsur yang menekankan begitu pentingnya sifat kasih sayang dan lemah lembut terhadap peserta didik. Inilah makna yang terkandung dalam hadits yang artinya: "aku bagi kalian tidak lain seperti orang tua bagi anaknya". Selain itu juga didasarkan atas paham Imam Al-Ghozali bahwa bila seorang pendidik telah memliki rasa kasih sayang yang tinggi terhadap anak didiknya, maka ia akan beusaha semaksimal mungkin untuk memberikan yang terbaik. Ini sifat yang diteladai dari Rosulullah dalam mendidik umatnya.

\footnotetext{
${ }^{24}$ Dokumentasi, 26 Desember 2019.

${ }^{25}$ Hamim, Abdullah Kafabihi Mahrus "Strategi Belajar Mengajar” Terjemah Ibya' 'Ulumuddin Bab Imu (t.t: Santri Salaf Pres, thn), 242.

160 | Tarbiyatuna: Jurnal Pendidikan Islam; Volume 13, Nomor 2, Agustus 2020, 151 -169 p-ISSN: 2085-6539; e-ISSN: 2242-4579
} 


\section{Implementasi Kode Etik dalam pembelajaran Pendidikan Agama Islam}

1. Membimbing peserta didik seutuhnya untuk membentuk manusia yang berjiwa Pancasila a. Teladan

Teladan adalah guru memberikan contoh perubahan perilaku maupun perkataan yang bisa memberi pengaruh lebih baik kepada peserta didik. Teladan yang digunakan oleh pendidik dalam pembelajaran pendidikan Agama Islam di SMA Negeri 1 Sukodadi Lamongan dalam mengimplementasikan kode etik, memberikan contoh berbusana yang disiplin dan baik kepada peserta didik. Hal ini sebagaimana yang disampaikan oleh Ely Makiyah bahwa ;

"Seorang guru itu sebagai panutan. Tingkah laku dan kebiasaan yang kita lakukan pasti di tiru oleh siswa.Menanamkan nilai-nilai kejujuran dalam dirinya, tegur sapa sesama teman dan juga kepada guru.Karena sejatinya guru itu digugu dan ditiru. Hal kecil yang bisa dilihat oleh peserta didik adalah cara berpakaian. Jika kita sebagai guru memakai pakaian ketat pasti peserta didik tidak fokus dengan apa yang kita jelaskan, melainkan mereka akan fokus ke fashion kita. Maka sebaiknya sebagai seorang pendidik cukup berpakaian sepantasnya saat mengajar, apalagi sebagai guru Agama."26

Selain memberikan suriteladan dalam berbusana pendidik PAI di SMA Negeri 1 Sukodadi juga memberikan contoh bagaimana cara menguasai pembelajaran dengan benar yaitu dengan cara seorang pendidik mempraktekan lebih dulu bagaimana cara membaca AlQur'an dengan baik dan benar. Ini di terapkan oleh Khafid Haqiqil Kirom juga menjelaskan bahwa ;

"Saya sebagai guru Agama harus mencontohkan bagaimana menjadi guru yang benar. Mengajar Agama itu mudah tapi susah, karena tidak hanya memberikan teori saja sebab apa yang kita ucapkan harus sesuai dengan apa yang kita lakukan. Contoh saja ketika pelajaran membaca Al-Qur'an, saya tidak hanya menyuruh tetapi saya juga harus memberikan contoh. Bagaimana cara membaca qur'an dengan benar. Sebab sebagai seorang guru perlu menguasai apa yang di ajarkan untuk peserta didiknya."27

Hal ini diperkuat oleh Mufidah salah satu siswa di SMA Negeri 1 Sukodadi Lamongan kelas XII yang diajar oleh Ely Makiyah bahwa;

"Bapak Ibu Guru kalau mengajar selalu tepat waktu, cara mengajarnya sangat mudah difahami tidak pernah melenceng, kalau pun ada pertanyaan yang aneh pasti di senyumi dulu lalu diterangkan sampai kita faham. Materi yang diajarkan selalu disangkut pautkan dengan keadaan sekitar dan juga pelajaran yang lain. dan pakaian yang digunakan sangat sopan sudah menunjukan bahwa dia seorang guru Agama." 28

\footnotetext{
${ }^{26}$ Ely Makiyah, Wawancara, 24 Desember 2019

${ }^{27}$ Khafid Haqiqil Kirom, Wawancara, 29 Februari 2020

${ }^{28}$ Mufidah, Wawancara, 20 Februari 2020.
} 


\section{b. Terbuka}

Terbuka adalah sebuah kreteria yang sangat penting bagi guru, menerima kedatangan, pertanyaan, kritik, hingga masukan dari siswa. Keterbukaan yang di gunakan oleh pendidik dalam pembelajaran Pendidikan Agama Islam seperti halnya menganggap mereka adalah teman diluar sekolah dan murid ketika dilingkup sekolah. Sebagaimana yang di ucapkan oleh Khafid Haqiqil Kirom mengatakan bahwa;

"Ketika di kelas saya menyuruh mereka memanggil saya dengan sebutan Bapak namun, jika di luar sekolah terserah mereka mau memanggil saya apa. Yang penting waktu disekolah saya sebagai guru dan mereka adalah murid.Bisa dikatakan saya adalah orang tua mereka di sekolahan dan ketika mereka sudah dirumah maka saya sudah lepas tangan.Tetapi jika saya mengetahui mereka melakukan kesalahan diluar sekolah, maka kewajiban saya sebagai guru adalah tetap mengingatkan mereka.Hal semacam itu saya terapkan di sekolah agar mereka lebih terbuka dengan saya." ${ }^{29}$

Tidak hanya menganggap mereka teman saja, agar mereka mau terbuka dengan pendidik. Seorang pendidik di SMA Negeri 1 Sukodadi Lamongan juga menganggap mereka sseperti anaknya sendiri. Sebagaimana yang di jelaskan oleh Ely Makiyah juga mengatakan bahwa ;

"Ketika saya mengajar, mereka sudah saya anggap seperti anak saya sendiri, dengan cara memberi mereka perhatian, dan menanyai mereka ada keluh kesah atau tidak. Karena menurut saya jika di sekolah mereka adalah anak dan saya adalah orang tua untuk mereka.Dengan hal semacam ini mereka dengan senang hati ingin bercerita atau curhat kepada saya.Dari situ saya jadi mengetahui ruang lingkup mereka, meskipun tidak semua siswa yang seperti itu." 30

Pemaparan ini diperkuat oleh salah satu kelas XII, M. Amyriel Syaifuddin menyatahkan bahwa ;

"Apa yang dijelaskan itu sesuai dengan kehidupan sehari-hari, cara mengajarnya pun tidak sepaneng, sehingga kita mudah faham dan tidak bosen.Saat pembelajaran diberi motivasi dari dirinya untuk murid-muridnya.Yang kurasakan Beliau seperti Ibu sendiri, Ketika ada yang salah maka akan dimarahi, dan ketika kita patuh tidak ada yang kena marah." ${ }^{31}$

2. Memiliki kejujuran professional

a. Fleksibel

Fleksibel di sini mempunyai arti bahwasanya seorang guru harus mempunyai prinsip, baik dalam nilai-nilai maupun pengetahuan begitupun juga tidak kaku dan mampu meneyesuaikan kondisi perkembangan, sifat, serta kemampuan peserta didik. Di SMA Negeri 1 Sukodadi mengimplementasikan nya dengan langkah membuat perjanjian sebelum pembelajaran di mulai. Hal ini seperti yang dibicarakan oleh Khafid Haqiqil Kirom bahwa ;

${ }^{29}$ Mufidah, Wawancara, 20 Februari 2020.

${ }^{30}$ Ely Makiyah, Wawancara, 24 Desember 2019.

${ }^{31}$ M. Amyriel Syaifuddin, Wawancara, 27 Februari 2020.

162 | Tarbiyatuna: Jurnal Pendidikan Islam; Volume 13, Nomor 2, Agustus 2020, 151 -169 p-ISSN: 2085-6539; e-ISSN: 2242-4579 
"Diawal pertemuan saya adakan perjanjian atau kontrak pembelajaran yang harus disepakati oleh semuanya baik saya ataupun peserta didik. Semisal saya telat, saya tetap masuk kalas dan memenuhi kebutuhan peserta didik saya. Dan andaikan ketika nanti peserta didik saya ada yang terlambat akan tetap saya beri absen, kecuali ketika sampai akhir dari pelajaran ada yang tidak masuk, maka itu yang saya beri alpha. Di antara saya dan peserta didik harus ada keterbukaan begitu pun juga dengan guru yang lain. Hal yang paling penting itu professional dan kewajiban tidak boleh ditiggalkan. Nah, Jika saya telat, maka yang pertama saya harus minta maaf dan saya akan memenuhi kebutuhan belajar mereka dengan cara menuntaskan materi yang saya ajarkan, jika tidak selesai maka akan ada tawar menawar dengan melanjutkan di pertemuan yang akan datang atau dibuat tugas. Begitu pula jika ada peserta didik yang telat, saya akan menanyakan dulu apa alasan mereka telat, karena menurut saya untuk masalah telat tidak perlu di permasalahkan, yang terpenting mereka terpenuhi kebutahannya." 32

Selain memberikan perjanjian sebelum pembelajaran dimulai, pendidik PAI SMA

Negeri 1 Sukodadi juga mengaitkan materi yang diajarkan dengan materi lain, seperti halnya yang dipaparkan oleh Ely Makiyah bahwa ;

"Dalam mengajar Pendidikan Agama Islam, materi yang paling di sukai anak-anak adalah bab Nikah. Di situ kesempatan saya menyangkut pautkan tentang kenakalan remaja, apa saja dampak kedepannya jika mereka melanggar norma dan agama. Dari apa yang sudah saya terangkan mereka lebih aktif bertanya soal pernikahan dan juga kenakalan remaja. Nah, dari situ materi yang awalnya hanya bab nikah menjadi lebih luas pemahaman yang peserta didik dapatkan. Tidak hanya itu dalam pelajaran pendidikan Agama Islam ada juga bab yang menjelaskan tentang terbentuknya manusia dalam surat al-alaq, nah disitu saya mengaitkan pelajaran pendidikan agama islam dengan pelajaran biologi. Jadi antara mata pelajaran satu dengan yang lain itu saling berkaitan dan sering sekali saya mengingatkan anak-anak sebisa mungkin kita harus menyukai seluru mata pelajaran, tanpa terkecuali. Hanya menyukai tidak mahir tidak masalah."33

Ajeng Fitri Larasati salah satu siswa yang di ajar oleh Khafid Haqiqil

Kirommenyatakan bahwa ;

"Meskipun telat beliau selalu masuk kelas, kalau tidak masuk atau ada acara dadakan pasti ada konfirmasi ke salah satu teman kita, jadi pelajarannya diganti dengan setoran hafalan.Waktu pembelajaran juga sangat mudah difahami, ringkas dan jelas.Dari banyaknya penjelasan diringkas dijadikan satu dan dibuat system pembelajaran yang b. Adil mudah difahami." 34

Adil adalah mampu menyikapi setiap siswa dengan karakter dan kemampuan yang beragam. Adil yang diberlakukan oleh pendidik dalam Pembelajaran Pendidikan Agama Islam di SMA Negeri 1 Sukodadi Lamongan dalam mengimplementasikan kode etik salah satunya toleransi sesama organisasi dalam hal hafalan doa sehari-hari. Khafid Haqiqil Kirom mengatakan bahwa ;

\footnotetext{
32 Khafid Haqiqil Kirom, Wawancara, 20 Maret 2020.

${ }^{33}$ Ely Makiyah, W awancara, 24 Desember 2019

34 Ajeng Fitri Larasati, Wawancara, 26 Februari 2020.
} 
"Saya disini memang mengajarkan Pendidikan Agama Islam.Dan di agama Islam tidak hanya ada Organisasi seperti Nahdotul ulama' saja, melainkan ada juga yang Muhamadiyah ataupun LDII.Dalam buku panduan yang diberikan kebanyakan Do'aDo'a versi NU sedangkan mereka yang tidak NU merasa kesulitan untuk menghafal atau memahami itu. Tugas saya sebagai guru mencari refrensi juga apa dan bagaimana yang diajarkan di setiap organisasi. Misalkan saja hafalan Qunut, nah di situ saya tidak akan memaksa mereka yang tidak pernah membaca qunut di waktu sholat, jadi saya mencarikan doa pengganti agar mereka semua sama-sama menghafalkan meski beda apa yang dihafalkan. Yang terpenting sebagai pendidik harus adil dalam memberikan kebutuhan peserta didik di sekolah." 35

Selain toleransi dalam Organisasi, pendidik PAI juga memberikan hukuman bagi yang salah dan memberikan apreseasi kepada yang baik. Ely Makiyah menyatakan bahwa ;

“ketika masuk kelas mengucapkan salam, berdo'a,setiap awal pelajaran membaca surat-surat pendek, atau menyanyikan lagu nasional. Lalu saya menyuruh mereka menghormati orang yang ada di depan untuk mendengarkan. Jadi ada perjanjian sebelumnya, siapa yang berbicara maka harus di dengarkan.Ketika mereka berbicara saya sebagai guru harus respon dan menanggapinya, jadi bukan hanya mereka saja yang harus mendengarkan. Di dalam pembelajaran pendidikan Agama Islam, tidak ada kata tidak adil. Saya memberlakukan semuanya sama. Jika ada yang salah pertama akan saya beri teguran, keselahan berikutnya akan saya panggil keruangan untuk berbicara empat mata dengan saya, dan jika ada yang benar atau melakukan hal yang bagus maka akan saya beri apreseasi. Apreasi ya bukan berupa barang atau apa, hanya tepuk tangan dan pujian yang sering tak berikan." 36

Hal ini diperkuat oleh M. Sifak Mashudi siswa yang diajakan oleh Ely Makiyah, bahwa ;

"Dalam kelas beliau tidak pernah membedakan antara satu dengan yang lain, semua disama ratakan. Kalau membedakan antar kelas ya pernah, seperti kebaikannya lalu kepandainnya katanya agar kita bisa berubah lebih baik dan tidak boleh kalah dengan kelas lainnya.Yang pernah dikatakan itu berlomba-lomba dalam kebaikan." ${ }^{37}$

\section{Model Implementasi Kode etik guru dalam Pembelajaran Pendidikan Agama Islam}

Model implementasi Kode etik di SMA Negeri 1 Sukodadi Lamongan yang dilakukan oleh guru dalampembelajaran Pendidikan Agama Islam adalah sebagai berikut ;

1. Pembiasaan

Pembiasaan adalah sesuatu yang sengaja dilakukan secara berulang-ulang agar sesuatu itu dapat menjadi kebiasaan. Dengan membiasakan peserta didik sebelum pelajaran dimulai dengan hal yang baik dan juga memberikan tugas, Ely Makiyah berpendapat bahwa ;

“Ketika masuk kelas mengucapkan salam, berdo'a, setelah itu setiap awal pelajaran membaca surat-surat pendek, atau menyanyikan lagu nasional. Hal semacam itu sudah menjadi kebiasaan buat saya sebelum pelajaran dimulai. Dan saya pribadi kalau memberikan tugas untuk anak-anak saya jadikan tugas kelompok, karena dengan adanya kerja kelompok mereka akan terbiasa tukar pendapat atau pun saling menghargai

\footnotetext{
${ }^{35}$ Khafid Haqiqil Kirom, Wawancara, 29 Februari 2020.

${ }^{36}$ Ely Makiyah, Wawancara, 22 Januari 2020.

${ }^{37}$ M. Sifak Mashudi, Wawancara, 26 Maret 2020.

164 | Tarbiyatuna: Jurnal Pendidikan Islam; Volume 13, Nomor 2, Agustus 2020, 151 -169 p-ISSN: 2085-6539; e-ISSN: 2242-4579
} 
pendapat teman-temannya. Setelah diskusi saya membiasakan mereka untuk bertanya, dengan tujuan agar mereka bisa menerima sebuah kritikan atau pun berfikir kritis." ${ }^{\prime 38}$

Bukan hanya itu, Ely Makiyah juga melanjutkan pemaparannya tentang model atau cara pembiasaan di sekolah bahwa;

"Kalau pun untuk kegiatan yang sudah terbiasa seperti Upacara bendera pada hari Senin, itukan sudah umum semua sekolah pasti sudah biasa dengan kegiatan Upacara, dan pasti berangkat akan lebih awal karena sudah terbiasa. Kemudian, senam bersama guru-guru pada hari Jum'at, tidak hanya guru saja, kepala sekolah atau pun waka-wakanya antusias, selalu kompak semuanya ikut dan mau berangkat lebih awal. Lalu, untuk kebiasaan bukan hanya itu, memakai sragam pun sudah menjadi kebiasaan tidak hanya dari atasan saja sebab semuanya sudah memberlakukan itu. "

Tidak hanya dengan pembiasaan sragam ataupun upacara. Tetapi dengan pembiasaan fingerprint mereka juga akan terbiasa, Khafid Haqiqil Kirom pun mengatakan bahwa ;

"Di sini tidak ada sanksi untuk guru, hanya saja jika ada kekeliruan ada teguran.Sebab sampai saat ini tidak ada yang melanggar dan terkena sanksi.Sudah terbiasa dengan profesi, kalau pun toh mau melanggar sering terbesit "saya kan pendidik tidak sepantasnya melakukan ini" sering keingat seperti itu. Untuk masalah masuk tepat waktu sudah diusahakan masuk lebih awal, meskipun sudah ada fingerprint, Karena kepala sekolah pun tidak akan memarahi karena semua sudah dilihat dari atasan, jika ada yang tidak ceklook maka yang dipotong bukan gajinya melainkan tunjangannya.Kalaupun kepala sekolah yang mengerti akan hal itu pasti di ingatkan." ${ }^{40}$

Ely Makiyah menambah pemaran ini bahwa ;

"Di SMA Negeri 1 Sukodadi ini juga menerapkan bagaimana memelihara hubungan kepada orang tua murid dengan tujuan menjadikan peserta didik di sini lebih baik. Misalkan, Ketika ada yang melanggar maka sanksi yang pertama cukup di ingatkan tapi jika sudah terlibat tiga kali orang tuanya yang dipanggil kesekolah, agar orang tua ini mengerti kesalahan apa yang dilakukan anaknya di sekolah. Jika masih tetap melakukan pelanggaran maka jangan pernah salahkan pada pihak sekolah yang akan mengeluarkan anaknya, karena sudah berulang kali diperingatkan, tapi masih saja melanggar. Semua ini diberlakukan untuk kepentingan pendidikan., ${ }^{41}$

\section{Teladan}

Teladan mempunyai arti yang penting dalam pendidikan, karenasetiap apa yang dilihat atau apa yang dikerjakan akan ditiru, baik oleh guru maupun peserta didiknya. Di sini kepala sekolah sudah memberikan contoh realnya seperti apa yang dikatakan oleh Khafid Haqiqil kirom bahwa ;

“Apa yang di berikan guru itu harus bagus karena guru itu di contoh.Kita tidak sedang membenarkan guru, melainkan itu sudah realitanya. Kepala sekolah sering mengingatkan

${ }^{38}$ Ely Makiyah, Wawancara, 22 Januari 2020.

${ }^{39}$ Ely Makiyah, Wawancara, 22 Januari 2020

${ }^{40}$ Khafid Haqiqil Kirom, $W$ awancara, 20 Maret 2020.

${ }^{41}$ Ely Makiyah, W awancara, 22 Januari 2020. 
tetap berperilaku baik agar peserta didik bisa meniru apa yang kita kerjakan. Dan memang beliau tidak bicara saja melainkan tindak lakunya itu nyata.Terkadang ada juga sebagaian guru yang banyak bicara tapi tidak berbuah nyata.Nah, disini banyak pengalaman yang bisa saya pelajari salah satunya adalah objektif." 42

Tidak hanya itu, cara memenegemen waktu juga perlu diteladani, seperti pendapat Ely

Makiyah bahwa ;

"Kepala sekolah yang baru ini memang sudah berusia, tapi jiwa nya masih milenia. Dari ucapannya yang tegas dan bisa di mengerti lalu perilakunya yang baik, bisa dijadikan contoh untuk para guru-guru lain. Beliau itu banyak jadwal tapi masih bisa membagi waktunya dengan baik.Ketika di sekolah pasti meneliti setiap ruang dan juga lingkungan sekolahnya, sekiranya ada yang perlu diperbaiki langsung di tindak lanjuti.Itu yang saya saluti.Tidak pernah memikirkan uang yang terpenting tujuan dari pendidikan itu di kedepankan atau di nomer satukan." 43

\section{Tabel 1.1}

Implementasi Kode Etik Guru dalam Pembelajaran Pendidikan Agama Islam di SMA Negeri 1 Sukodadi Lamongan

\begin{tabular}{|c|c|c|c|}
\hline No & Fokus & Temuan & Teori \\
\hline 1. & 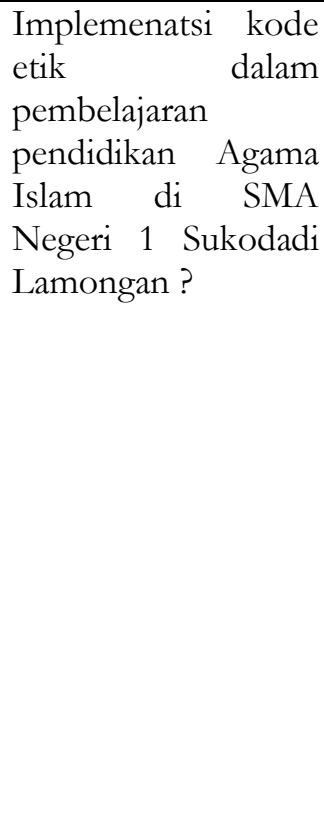 & $\begin{array}{l}\text { Di SMA Negeri } 1 \text { Sukodadi } \\
\text { Lamongan implementasi kode etik } \\
\text { dilakukan melalui cara sebagai } \\
\text { berikut; } \\
\text { 1. Menjadi Teladan, yakni } \\
\text { memberikan contoh yang baik } \\
\text { kepada peserta didiknya. seperti } \\
\text { berpakain yang benar dan } \\
\text { berkata dengan sopan. Tidak } \\
\text { hanya terkait dengan fisiknya } \\
\text { saja, karena tidak memberikan } \\
\text { teori saja tapi juga } \\
\text { mempraktekan langsung apa } \\
\text { yang di bicarakan, seperti halnya } \\
\text { menghafal surat-surat pendek } \\
\text { yang sebelumnya diberikan } \\
\text { contoh terlebih dulu, agar } \\
\text { peserta didik bisa membaca } \\
\text { dengan baik dan benar. }\end{array}$ & $\begin{array}{lr}\text { Ki Hajar } & \text { dewantara } \\
\text { bahwasanya } & \text { guru } \\
\text { dituntut } & \text { menjadi } \\
\text { figure ing ngarsa sung } \\
\text { tuladha, ing madya } \\
\text { mangun karsa, tut wuri } \\
\text { bandayani. Yang mana } \\
\text { dapat di artikan } \\
\text { bahwasanya } r \text { sikap } \\
\text { pendidik } & \text { harus } \\
\text { mampu } & \text { memberi } \\
\text { teladan } & \text { kepada } \\
\text { peserta } & \text { didiknya } \\
\text { dalam penanaman } \\
\text { budi pekerti }\end{array}$ \\
\hline & & $\begin{array}{l}\text { 2. Lebih Terbuka, dimana } \\
\text { Guru Pendidikan Agama Islam } \\
\text { memberikan kebebasan untuk } \\
\text { memanggil diluar sekolah. Hal } \\
\text { ini dilakukan agar para peserta } \\
\text { didik bisa saling terbuka dan } \\
\text { bebas meneyampaikan apa yang } \\
\text { mereka rasakan. Bukan hanya itu } \\
\text { para peserta didik juga sudah di }\end{array}$ & $\begin{array}{lr}\text { M.I, } & \text { Soelaeman } \\
\text { menyatakan bahwa } \\
\text { tugas guru meliputi } \\
\text { kasih sayang kepada } \\
\text { peserta didiknya } \\
\text { karena di sekolah } \\
\text { dipandang sebagai } \\
\text { pengganti orang tua, } \\
\text { penjaga, pelindung }\end{array}$ \\
\hline
\end{tabular}

42 Khafid Haqiqil Kirom, Wawancara, 20 Maret 2020.

${ }^{43}$ Ely Makiyah, Wawancara, 22 Januari 2020.

166 | Tarbiyatuna: Jurnal Pendidikan Islam; Volume 13, Nomor 2, Agustus 2020, 151 -169 p-ISSN: 2085-6539; e-ISSN: 2242-4579 


\begin{tabular}{|c|c|c|c|c|}
\hline & & & $\begin{array}{l}\text { anggap seperti anaknya sendiri, } \\
\text { dengan cara mengingatkan } \\
\text { mereka ketika mereka salah dan } \\
\text { memberikan penghargaan atau } \\
\text { meluruskan meski sudah benar. }\end{array}$ & $\begin{array}{l}\text { dan pengasuh } \\
\text { anak,penyambung } \\
\text { lidah dan tang orang } \\
\text { tua. }\end{array}$ \\
\hline & & & $\begin{array}{l}\text { Fleksibel atau kreatif yakni } \\
\text { Sebelum pembelajaran di mulai } \\
\text { ada perjanjian antara guru dan } \\
\text { peserta didik. Sebab sebagai guru } \\
\text { harus professional dalam } \\
\text { mengajar, menyampaikan materi } \\
\text { dengan jelas dan lugas agar } \\
\text { peserta didik mudah } \\
\text { memahaminya dan menuntaskan } \\
\text { materi yang diberikan kepada } \\
\text { peserta didik agar mereka } \\
\text { terpenuhi kebutuhannya. Dalam } \\
\text { memberikan materi, dan } \\
\text { mengaitkan pelajaran lain dalam } \\
\text { materi disampaikan, karena } \\
\text { dengan hal itu akan menambah } \\
\text { wawasan kepada peserta didik } \\
\text { dan pengetahuan mereka akan } \\
\text { lebih luas. }\end{array}$ & $\begin{array}{l}\text { Mahmud Samir al- } \\
\text { Munir bahwa seorang } \\
\text { guru fleksibel bisa } \\
\text { dikatakan juga kreatfi } \\
\text { yakni harus memiliki } \\
\text { bekal dan persiapan } \\
\text { agar dapat } \\
\text { menjalankan profesi } \\
\text { dan risalahnya. Seperti } \\
\text { halnya menguasai } \\
\text { materi dengan matang } \\
\text { dan mampu } \\
\text { memberikan } \\
\text { pemahaman kepada } \\
\text { peserta didik secara } \\
\text { baik. }\end{array}$ \\
\hline & & & $\begin{array}{l}\text { Bersikap Adil Sebagai seorang } \\
\text { guru sudah sepatutnya berlaku } \\
\text { adil kepada semua peserta } \\
\text { didiknya. Guru pendidikan } \\
\text { Agama Islam di SMA Negeri } 1 \\
\text { Sukodadi memberlakukan sama } \\
\text { terhadap semua peserta didiknya. } \\
\text { Tidak pernah membedakan apa } \\
\text { golongan yang mereka anut, } \\
\text { memberikan kefahaman yang } \\
\text { sesuai dengan faham mereka, } \\
\text { dan jika melakukan kesalahan } \\
\text { akan diberi sanksi sesuai dengan } \\
\text { apa yang dilanggar. Jadi, baik } \\
\text { dalam segi ekonomi maupun } \\
\text { golongan semua siswa tidak ada } \\
\text { yang di unggulkan dan tidak ada } \\
\text { yang di rendahkan. }\end{array}$ & $\begin{array}{l}\text { Roestiyah, N.K dalam } \\
\text { bukunya bahwasanya } \\
\text { seorang guru harus } \\
\text { mampu menimbulkan } \\
\text { semangat belajar } \\
\text { individual. Masing- } \\
\text { masing peserta didik } \\
\text { mempunyai } \\
\text { perbedaan dalam } \\
\text { pengalaman, dan sifat- } \\
\text { sifat pribadi yang lain } \\
\text { sehingga dapat } \\
\text { memberi kebabasan } \\
\text { pada peseta didik } \\
\text { untuk mengembangkan } \\
\text { kemampuan berfikir }\end{array}$ \\
\hline 2. & $\begin{array}{l}\text { Bagaimana model } \\
\text { implemenasti } \\
\text { etik gode } \\
\text { pembelajaran } \\
\text { pendidikan Agama } \\
\text { Islam di SMA } \\
\text { Negeri } 1 \text { Sukodadi } \\
\text { Lamongan }\end{array}$ & & $\begin{array}{l}\text { Model pembiasan yang } \\
\text { dilakukan di SMA Negeri } 1 \\
\text { Sukodadi dalam pembelajaran } \\
\text { pendidikan Agama Islam , } \\
\text { seperti halnya berdo'a sebelum } \\
\text { belajar, menyanyikan lagu } \\
\text { nasional, membaca surat-surat } \\
\text { pendek, dengan pembiasaan } \\
\text { seperti itu bisa menumbhuhkan } \\
\text { jiwa pancasila dalam diri peserta } \\
\text { didik. Lalu memberikan mereka } \\
\text { tugas kelompok dan } \\
\text { membiasakan peserta didik } \\
\text { bertanya. Karena dengan adanya }\end{array}$ & $\begin{array}{lr}\text { Armai } & \text { Arief } \\
\text { bahwasanya } & \\
\text { Pembiasan } & \text { dapat } \\
\text { diartikan } & \text { dengan } \\
\text { proses } & \text { membuat } \\
\text { sesuatu atau seseorang } \\
\text { menjadi } & \text { terbiasa. } \\
\text { Dalam } & \text { kaitanya } \\
\text { dengan } & \text { metode } \\
\text { pengajaran } & \text { dalam } \\
\text { pendidikan } & \text { Agama } \\
\text { Islam, dapat dikatakan } \\
\text { bahwa pembiasaan } \\
\text { adalah sebuah cara }\end{array}$ \\
\hline
\end{tabular}




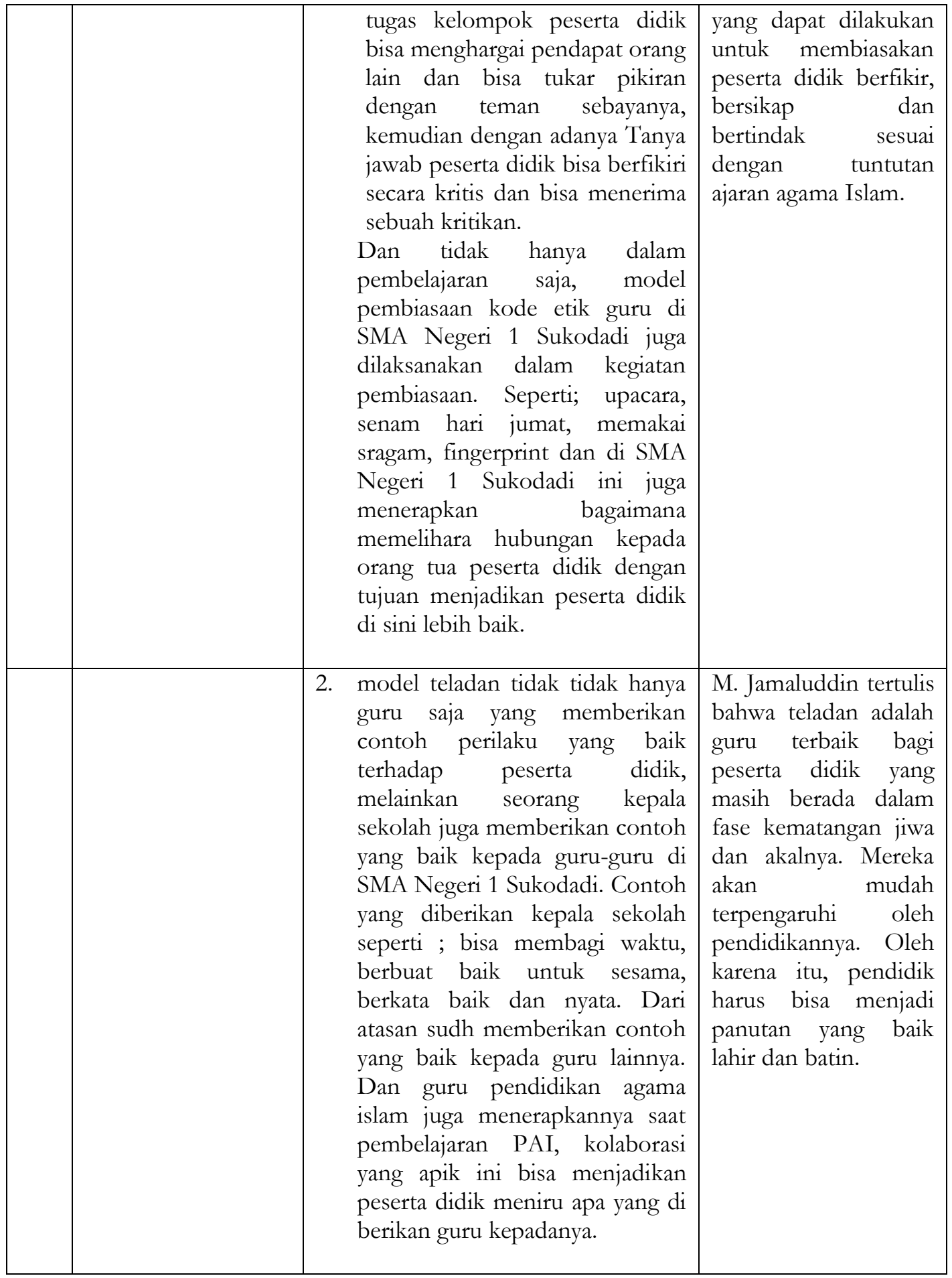

\section{Kesimpulan}

Berdasarkan hasil penelitian tentang implementasi kode etik guru dalam pembelajaran pendidikan agama Islam di SMA Negeri 1 Sukodadi Lamongan, didapati bahwa dari delapan kode etik guru yang berlaku. Sebagaimana yang dapat ditarik kesimpulannya bahwa implementasi kode etik guru dalam pembelajaran pendidikan agama Islam di SMA Negeri 1 Sukodadi Lamongan 
dilakukan dengan cara keteladanan, terbuka, fleksibel, dan adil. Sedangkan yang diterapkan oleh guru beserta kepala sekolah melalui pembiasaan dan keteladan.

\section{Referensi}

Armai, Arief. 2002. Pengantar ilmu dan Metodologi Pendidikan Islam, Jakarta: Ciputat Press.

Darajat, Zakiyah dkk, 2008. Ilmu Pendidikan Islam, Jakarta: Bumi Aksara, 2008.

Departemen Agama RI. 2005. Al-Qur'an dan terjemahnya, Bandung: CV Penerbit J-ART, 2005.

Hamim, Abdullah Kafabihi Mahrus. "Strategi Belajar Mengajar" Terjemah Ibya' 'Ulumuddin Bab Ilmu, t.t: Santri Salaf Pres, thn.

Hawi, Akmal. 2013. Kompetensi Guru Pendidikan Agama Islam, Jakarta: PT Raja Grafindo Persada

Rahman, Muhammad; dan Amri, Sofan. 2014. Kode Etik Profesi Guru Legalitas, Realitas, dan Harapan, Jakarta: Prestasi Pustakarya.

Syafruddin, Nurdin, Andriantoni. 2019. Profesi Keguruan. Jakarta: PT Rajagrafindo Persada

Tafsir, Ahmad. 2013. Ilmu Pendidikan Islam, Bandung: PT Remaja Rosdakarya Offset

Ulumuddin, M. Fatchul. "Implementasi Pendidikan Karakter Melalui Pembelajaran Pendidikan Agama Islam di MTs. Al-Ihsan Pondok Pesantren Darul Fiqhi Deket Lamongan" (Skripsi - Universitas Islam Lamongan, 2019).

Undang-Undang RI No 8 tahun 1974 Tentang Pokok-pokok Kepegawaian, Jakarta: Prestasi Pustakarya, 2014. 